\title{
The Effect of Electronic Word of Mouth, Brand Image, Customer Trust and Customer Satisfaction towards Repurchase Intention at PT. GO-JEK Indonesia
}

\author{
Ria Arumsari ${ }^{1}$, Maya Ariyanti ${ }^{2}$ \\ ${ }^{1,2}$ Telkom University, School of Business and Economics, Jl. Telekomunikasi Terusan Buah Batu Bandung 40257 Indonesia
}

\begin{abstract}
With the rapid development of technology, then now began to emerge companies that take advantage of these technological developments. One of them is the emergence of online business service providers of transportation. PT. GO-JEK Indonesia is a pioneer company that initiated an online motorcycle taxi service in Indonesia. Currently, there have been other online motorcycle companies that have actively activated. Thus, in order to continue to compete, PT. GO-JEK Indonesia should encourage customers to conduct repeat purchase activities. This study aims to know factors that drive repurchase intention at PT. GO-JEK Indonesia. Quantitative research with causal type of study is used in the research. The studied samples were processed by method namely convenience sampling with total sampling of 400 respondents. Data collection method use questionnaire, were collected through google form accros nations, and use SEM for data analysis techniques. The result conclusion shows that all categories fall into either category because it is in the range between $68 \%$ to $84 \%$. Partially, almost all hypotheses are quite significant. Will, for E-WOM hypothesis significant against repeated intention rejected. Simultaneously, E-WOM variables, brand image, customer trust and customer satisfaction in this study have a significant influence on the intention to buy back at PT. GO-JEK Indonesia is $59.3 \%$, while the remaining $40.7 \%$ is owned by other factors not examined in this research.
\end{abstract}

Keywords: Electronic Word Of Mouth (E-WOM), Brand Image, Customer Trust, Customer Satisfaction, Repurchase Intention

\section{Introduction}

Currently, the development of technology is quite rapid and the development of this technology is very closely related to the internet. This can provide a change in social life in the community, how to communicate a person as well as a distinct opportunity for the business. In 2014 shows the penetration of internet users in Indonesia by $34.9 \%$ and in 2016 increased, so it was in the position of $51.8 \%^{[1]}$. According to Jamalul Izza (APJII chairman), the increase is due to the development of infrastructure and the ease of getting a smartphone or handheld device ${ }^{[2]}$.

By $201577 \%$ of Indonesia's population, equivalent to 196.7 million people, has mobile phones and $41.7 \%$ are smartphone users. By looking at these conditions, now began emerging companies that take advantage of the development of communication technology, one of which is the emergence of business providers of online transportation services ${ }^{[3]}$. PT. GO-JEK Indonesia is a pioneer company that initiated an online motorcycle taxi service in Indonesia. Lately, there have been other online motorcycle companies that have been actively operating such as Grab, Uber, LadyJek, Syar'I Ojek, Wheel Line, Teknojek, TransJek, and Bangjek. In this study, this study only compares between GO-JEK, Uber and Grab because the three online transport service companies are the largest and most widely used ${ }^{[4]}$.

In 2015, it was mentioned that GO-JEK is the most popular application by the community of $65.9 \%$ of the respondents spread, followed by Grab $37.15 \%$ and Uber $15.52 \%{ }^{[5]}$. Competition between the three online motorcycle companies is very tight, it can be seen how many drivers they have, the setting of rates, how they provide services to customers, the type of service they provide, and so on. These aspects are very important for someone to buy back, but the determination of tariffs is a very important point in the competition between the three companies ojek online. This is because, if GO-JEK raises its tariff, then consumers can move using other online transport applications. In running the online transport business, GO-JEK did not escape the problems that came. Although GO-JEK is superior to Grab and Uber. There are still customers who are less satisfied with the services that GO-JEK provide. This can be a threat to the GO-JEK company. In addition, lately, there is a demonstration of a conventional motorcycle taxi. Conventional motorcycle taxis are less agree with the presence of ojek online. Currently, there are still some areas where online motorcycle taxis can not enter the area. Thus, this issue becomes one big question whether in the future online motorcycle taxi service will remain as today or not. By looking at the above phenomenon, in order to keep down the use of GO-JEK applications, GO-JEK must know what factors can affect repurchase intention.

\section{Literature Review}

\section{a) E-WOM}

E-WOM is one communication medium to share information about a product or service, where the product or service has been consumed. This communication through entering customers who do not know each other and meet before ${ }^{[6]}$. There are four dimension of E-WOM: (1) intensity, (2) positive valance, (3) negative valance, (4) content ${ }^{[7]}$. 


\section{International Journal of Science and Research (IJSR) \\ ISSN (Online): 2319-7064}

Index Copernicus Value (2015): 78.96 | Impact Factor (2015): 6.391

\section{b) Brand Image}

Brand as a name, sign, symbol, or design, or a combination of them, itended to identify, the goods or services of one seller or group of sellers and to differentiate them from those of competitors ${ }^{[8]}$. Brand image refers to the schematic memory of a brand. It contains the target market's interpretation of the product's attributes, benefits usage situations, users, and manufacturer/marketer characterristics. It is what people think of and fell when they hear or see a brand name ${ }^{[9]}$.

\section{c) Customer Trust}

Trust is a psychological state which consists of the intention to accept vulnerability, based on positive expectations of intent or other behavior ${ }^{[10]}$.

\section{d) Customer Satisfaction}

Satisfaction is a feeling of pleasure or disappointment that emerged after comparing the perception of product performance $^{[11]}$. Satisfaction can also be said as a customer evaluation of a product or service, whether this is in accordance with the needs and expectations of the customer itself $^{[12]}$.

\section{e) Repurchase Intention}

Repurchase intention is the intention to buy back a brand from a product ${ }^{[13]}$. Where this happens because the consumer has bought a product or service before.

\section{Methodology}

This research belongs to quantitative research, whereas based on its purpose this research belongs to descriptive study with emphasis on a causal relation. Sampling technique used in this research is nonprobability sampling with convenience sampling method. Respondents consisted of 400 customers of PT. GO-JEK Indonesia who has been using GO-JEK applications. Data analysis techniques use structural equation modeling analysis with the help of SmartPLS 2.0.

\subsection{Research Framework}

Based on existing literature about purchase intention, this framework is constructed to illustrate factors affecting purchase intention:

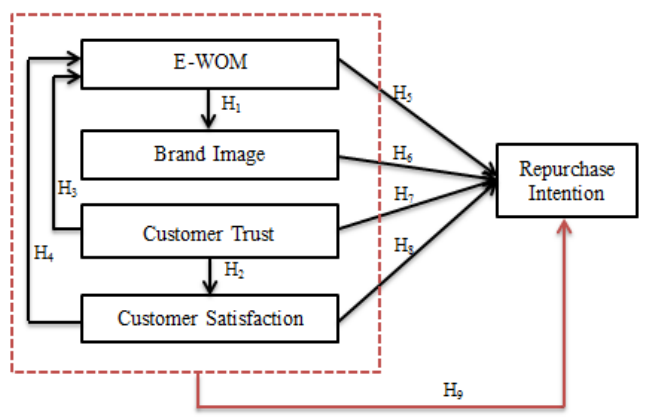

Figure 1 : Research Framework

The hypothesis that will be tested is as follow:

H1 : There's significant influence of E-WOM toward brand image.
H2 : There's significant influence of customer trust toward customer satisfaction

H3 : There's significant influence of customer trust toward E-WOM.

H4 : There's significant influence of customer satisfaction toward E-WOM.

H5 : There's significant influence of E-WOM toward repurchase intention.

H6 : There's significant influence of brand image toward repurchase intention.

H7 : There's significant influence of customer trust toward repurchase intention.

H8 : There's significant influence of customer satisfaction toward repurchase intention.

H9 : There's significant influence of E-WOM, brand image, customer trust and customer satisfaction toward rerchase intention.

\subsection{Data Collection}

This research belongs to quantitative research, whereas based on its purpose this research belongs to descriptive study with emphasis on a causal relation. Sampling technique used in this research is nonprobability sampling with convenience sampling method. Respondents consisted of 400 customers of PT. GO-JEK Indonesia who has been using GO-JEK applications. Data analysis techniques use structural equation modeling analysis with the help of SmartPLS 2.0.

Table 3.1: Demographic Characteristics of Respondent

\begin{tabular}{|c|c|c|}
\hline Age Characteristic & Frequency & Percentage \\
\hline 21 or under & & \\
\hline $21-25$ & 109 & $27,25 \%$ \\
\hline $26-30$ & 239 & $59,75 \%$ \\
\hline $31-35$ & 18 & $4,5 \%$ \\
\hline above 35 & 7 & $1,75 \%$ \\
\hline Gender & 27 & $6,75 \%$ \\
\hline Female & 227 & $69,3 \%$ \\
\hline Male & 123 & $30,8 \%$ \\
\hline Occupation & & \\
\hline Student & 23 & $5,75 \%$ \\
\hline College & 204 & $51 \%$ \\
\hline Civil Servants & 15 & $3,75 \%$ \\
\hline Private Employees & 100 & $25 \%$ \\
\hline Entrepreneur & 22 & $5,5 \%$ \\
\hline Et al & 36 & $9 \%$ \\
\hline Frequently Used Services & & \\
\hline GO-RIDE & 262 & $65,5 \%$ \\
\hline GO-CAR & 28 & $7 \%$ \\
\hline GO-FOOD & 99 & $24,75 \%$ \\
\hline GO-PULSA & 2 & $0,5 \%$ \\
\hline GO-MASSAGE & 1 & $0,25 \%$ \\
\hline GO-SEND & 8 & $2 \%$ \\
\hline
\end{tabular}

\section{Result and Discussions}

\subsection{Outer Model}

Data analysis techiniques using Smart PLS 2.0 to test model. Measurement model is necessary to determine validity and reliability of this model. Validity test consists of convergent validity and discriminant validity. Convergent Validity will

Volume 6 Issue 7, July 2017 www.ijsr.net 


\section{International Journal of Science and Research (IJSR) \\ ISSN (Online): 2319-7064 \\ Index Copernicus Value (2015): 78.96 | Impact Factor (2015): 6.391}

be stated as valid if value of Loading Factors of each indicators > 0.50 and Average Variance Extracted (AVE) > 0.50 for each construct. Discriminant Validity will be stated as valid if value of cross loading in which the value with its latent variable is bigger than value of other latent variable.

From table 4.3 below, all of indicators have loading factor value $>0.50$ and all of constructs have AVE $>0.50$, thus all indicators of constructs are valid for convergen validity. Also, all of cross loadings (the bold numbers) value is bigger than value of other latent variable, thus the model is accepted to fulfill requirements for discriminant validity.

Reliability measured by inferring to value of Composite Reliability (CR) and Cronbach's Alpha of each constructs. A construct can be stated as reliable if $\mathrm{CR}>0.70$ or can be accepted between 0.60-0.70 and Cronbach's Alpha $>0.70$. The following table contains all reliability value of this model:

Table 4.4 Reliability Model

\begin{tabular}{|c|c|c|c|}
\hline Construct & Cronbachs Alpha & Composite Reliability & Description \\
\hline E-WOM & 0,923 & 0,938 & Reliable \\
\hline BI & 0,873 & 0,909 & Reliable \\
\hline CS & 0,874 & 0,914 & Reliable \\
\hline CT & 0,914 & 0,932 & Reliable \\
\hline RI & 0,912 & 0,932 & Reliable \\
\hline WF & 0.701 & 0.842 & Reliable \\
\hline
\end{tabular}

All of constructs has Composite Reliability (CR) and Cronbach's Alpha Reliable. Thus it can be concluded this model is reliable.

\subsection{Inner Model}

Inner model is well known as structural model test. Structural test consists $\mathrm{R}^{2}$ to see how much independent variables can explain the dependent variable and $\mathrm{Q}^{2}$ to predictive relevance to estimates whether a model have predicting power or not.

Table 4.5: Inner Model Test

\begin{tabular}{|c|c|c|}
\hline Laten Endogen Construct & $\mathrm{R}^{2}$ & $\mathrm{Q}^{2}$ \\
\hline $\mathrm{RI}$ & 0.593 & 0.405 \\
\hline
\end{tabular}

The value of $\mathrm{Q}^{2}$ can be stated as good of predicted relevance $\mathrm{Q}^{2}>0$. From following table, value of $\mathrm{R}^{2}$ for Repurchase Intention construct is 0.593 it means that all elements such as
E-WOM, brand image, customer trust, and customer satisfaction can explain $59.3 \%$ of repurchase intention. The rest of it, $40.7 \%$ is influenced by other factors. The result of $\mathrm{Q}^{2}$ is above value 0 , it means that the model has predictive relevance. From all indicators it can be concluded that this model is acceptable.

\subsection{Hypothesis Testing}

In this research hypothesis are testing using two-tails method with significance level of 5\%. The requirement is accepted when $\mathrm{t}$-statistic $\geq 1.96 ; \mathrm{p}$ value 0.05 and rejected when $\mathrm{t}$ statistic <1.96; p value 0.05 .

Table 4.6: Hypothesis Testing $\mathrm{t}$

\begin{tabular}{|c|c|c|c|c|}
\hline Hypothesis & Path & $\begin{array}{c}\text { Path } \\
\text { Coefficient }\end{array}$ & t statistic & Description \\
\hline H1 & E-WOM -> BI & 0,533 & 6,780 & Accepted \\
\hline H2 & CT -> CS & 0,614 & 9,360 & Accepted \\
\hline H3 & CT -> E-WOM & 0,296 & 2,544 & Accepted \\
\hline H4 & CS -> E-WOM & 0,335 & 2,985 & Accepted \\
\hline H5 & E-WOM -> RI & 0,133 & 1,489 & Rejected \\
\hline H6 & BI -> RI & 0,227 & 1,969 & Accepted \\
\hline H7 & CT -> RI & 0,236 & 2,550 & Accepted \\
\hline H8 & CS -> RI & 0,316 & 3,009 & Accepted \\
\hline
\end{tabular}

The value of path coefficient indicates a positive or negative influence of latent exogen constructs toward latent endogen construct. From the hypothesis t tested, the results show that only a few variables have significant influence. It is found that E-WOM positive significant influences brand image, thus $\mathrm{H} 1$ is accepted. $\mathrm{H} 2$ is accepted, customer trust positive significance influences customer satisfaction. H3 is accepted, customer trust positive significant influences E-WOM. Customer satisfaction positive significant influences EWOM, thus H4 is accepted. H4 is rejected, because E-WOM doesn't have positive significant influences repurchase intention. But, brand image (H5), customer trust (H6) and customer satisfaction (H7) have positive significant influences repurchase intention.

$\mathrm{H} 8$ is tested using this equation below, $\mathrm{H} 8$ accepted if $\mathrm{F}_{\text {research }}$ $\geq \mathrm{F}_{\text {table, }}$, where $\mathrm{F}_{\text {table }}=\mathrm{F}_{(0,05 ; 4 ; 395)}=2,395$ and rejected if if $\mathrm{F}_{\text {research }}<\mathrm{F}_{\text {table }}$.

$$
F=\frac{R^{2} / k}{\left(1-R^{2}\right) /(n-k-1)}
$$

Table 4.3 Validity Model

\begin{tabular}{|c|c|c|c|c|c|c|c|c|c|}
\hline \multirow{2}{*}{$\begin{array}{c}\text { Latent } \\
\text { Variable }\end{array}$} & \multirow{2}{*}{ Indicator } & \multirow{2}{*}{$\begin{array}{l}\text { Loading } \\
\text { Factor }\end{array}$} & \multicolumn{5}{|c|}{ Cross Loading } & \multirow{2}{*}{ AVE } & \multirow{2}{*}{ Description } \\
\hline & & & EWOM & BI & CT & $\mathrm{CS}$ & RI & & \\
\hline \multirow{7}{*}{ E-WOM } & $\mathrm{EWOM}_{1}$ & 0,844 & 0,844 & 0,422 & 0,421 & 0,388 & 0,388 & \multirow{7}{*}{0,685} & Valid \\
\hline & $\mathrm{EWOM}_{2}$ & 0,826 & 0,826 & 0,423 & 0,361 & 0,414 & 0,378 & & Valid \\
\hline & $\mathrm{EWOM}_{3}$ & 0,799 & 0,799 & 0,388 & 0,372 & 0,344 & 0,377 & & Valid \\
\hline & $\mathrm{EWOM}_{4}$ & 0,860 & $\mathbf{0 , 8 6 0}$ & 0,458 & 0,431 & 0,432 & 0,463 & & Valid \\
\hline & $\mathrm{EWOM}_{5}$ & 0,714 & 0,714 & 0,377 & 0,379 & 0,384 & 0,431 & & Valid \\
\hline & EWOM $_{6}$ & 0,877 & $\mathbf{0 , 8 7 7}$ & 0,505 & 0,488 & 0,518 & 0,524 & & Valid \\
\hline & $\mathrm{EWOM}_{7}$ & 0,864 & 0,864 & 0,492 & 0,433 & 0,478 & 0,511 & & Valid \\
\hline \multirow{3}{*}{ Brand Image } & $\mathrm{BI}_{1}$ & 0,896 & 0,505 & 0,896 & 0,524 & 0,663 & 0,633 & \multirow{3}{*}{0,667} & Valid \\
\hline & $\mathrm{BI}_{2}$ & 0,724 & 0,400 & 0,724 & 0,362 & 0,524 & 0,459 & & Valid \\
\hline & $\mathrm{BI}_{3}$ & 0,839 & 0,494 & 0,839 & 0,513 & 0,637 & 0,547 & & Valid \\
\hline
\end{tabular}




\section{International Journal of Science and Research (IJSR) ISSN (Online): 2319-7064}

Index Copernicus Value (2015): 78.96 | Impact Factor (2015): 6.391

\begin{tabular}{|c|c|c|c|c|c|c|c|c|c|}
\hline & $\mathrm{BI}_{4}$ & 0,756 & 0,361 & 0,756 & 0,448 & 0,583 & 0,519 & & Valid \\
\hline & $\mathrm{BI}_{5}$ & 0,854 & 0,400 & 0,854 & 0,468 & 0,619 & 0,553 & & Valid \\
\hline \multirow{7}{*}{$\begin{array}{c}\text { Customer } \\
\text { Trust }\end{array}$} & $\mathrm{CT}_{1}$ & 0,854 & 0,467 & 0,500 & 0,854 & 0,523 & 0,548 & \multirow{7}{*}{0,728} & Valid \\
\hline & $\mathrm{CT}_{2}$ & 0,708 & 0,333 & 0,315 & 0,708 & 0,318 & 0,355 & & Valid \\
\hline & $\mathrm{CT}_{3}$ & 0,819 & 0,406 & 0,496 & $\mathbf{0 , 8 1 9}$ & 0,571 & 0,519 & & Valid \\
\hline & $\mathrm{CT}_{4}$ & 0,853 & 0,434 & 0,484 & 0,853 & 0,517 & 0,571 & & Valid \\
\hline & $\mathrm{CT}_{5}$ & 0,763 & 0,347 & 0,444 & 0,763 & 0,486 & 0,448 & & Valid \\
\hline & $\mathrm{CT}_{6}$ & 0,822 & 0,409 & 0,476 & 0,822 & 0,518 & 0,518 & & Valid \\
\hline & $\mathrm{CT}_{7}$ & 0,865 & 0,441 & 0,500 & 0,865 & 0,522 & 0,569 & & Valid \\
\hline \multirow{4}{*}{$\begin{array}{l}\text { Customer } \\
\text { Satisfaction }\end{array}$} & $\mathrm{CS}_{1}$ & 0,877 & 0,465 & 0,644 & 0,551 & $\mathbf{0 , 8 7 7}$ & 0,597 & \multirow{4}{*}{0,662} & Valid \\
\hline & $\mathrm{CS}_{2}$ & 0,901 & 0,453 & 0,702 & 0,552 & 0,901 & 0,663 & & Valid \\
\hline & $\mathrm{CS}_{3}$ & 0,786 & 0,411 & 0,609 & 0,426 & 0,786 & 0,542 & & Valid \\
\hline & $\mathrm{CS}_{4}$ & 0,844 & 0,431 & 0,580 & 0,557 & 0,844 & 0,578 & & Valid \\
\hline \multirow{6}{*}{$\begin{array}{l}\text { Repurchase } \\
\text { Intention }\end{array}$} & $\mathrm{RI}_{1}$ & 0,799 & 0,440 & 0,521 & 0,530 & 0,556 & 0,799 & \multirow{6}{*}{0,694} & Valid \\
\hline & $\mathrm{RI}_{2}$ & 0,825 & 0,441 & 0,566 & 0,573 & 0,605 & 0,825 & & Valid \\
\hline & $\mathrm{RI}_{3}$ & 0,866 & 0,507 & 0,592 & 0,536 & 0,629 & 0,866 & & Valid \\
\hline & $\mathrm{RI}_{4}$ & 0,823 & 0,389 & 0,561 & 0,469 & 0,584 & $\mathbf{0 , 8 2 3}$ & & Valid \\
\hline & $\mathrm{RI}_{5}$ & 0,895 & 0,509 & 0,581 & 0,542 & 0,587 & 0,895 & & Valid \\
\hline & $\mathrm{RI}_{6}$ & 0,787 & 0,383 & 0,514 & 0,479 & 0,528 & $\mathbf{0 , 7 8 7}$ & & Valid \\
\hline
\end{tabular}

description :

$\mathrm{R}^{2}=\mathrm{R}$ Square

$\mathrm{K}$ = number of variabel exogen

$\mathrm{n}=$ number of sample

$$
F=\frac{(400-4-1) 0,593}{4(1-0,593)}=143,581
$$

From analysis result, it shows that $F_{\text {research } 143,581 \geq F_{\text {table }}}$ 2,395. Thus H8 is also accepted, E-WOM, brand image, customer trust, and customer satisfaction positive significant influences repurchase intention.

\subsection{Discussion}

From the result of respondent's characteristic, it can be seen that the respondent based on age 21-25 year equal to $59,75 \%$ which is having a job as a student $(51 \%)$. While genderbased on $69.3 \%$ female and $30.8 \%$ male, this indicates that customers who often use the application of GO-JEK are women, however, the target of PT. GO-JEK itself is not limited to gender. Users of GO-JEK applications are also scattered in various cities in Indonesia, but the most widely used customers GO-JEK applications are in big cities with the type of service used is GO-RIDE. Currently, GO-RIDE has won the competition in Indonesia and has been actively used by 10 million people every week ${ }^{[14]}$. In addition, the introduction of digital food features or GO-FOOD has dominated $95 \%$ market share in Indonesia. This is in accordance with the results of research on the characteristics of respondents, which states that GO-FOOD service is the most widely used service after GO-RIDE.

Based on the results of descriptive analysis, E-WOM variable, brand image, customer trust, customer satisfaction and repurchase intention at PT. GO-JEK Indonesia as a whole is included in either category. Of the 29 statements of respondents' answers to these variables, obtained an average total score of between $68 \%$ to $84 \%$. This shows that the variables are at PT. GO-JEK Indonesia as a whole has been good in the eyes of consumers or customers.
From all of the outer model test, inner model test, it is found that this model is viable to be tested. The result from hypothesis testing shows e-wom influences brand image with a path coefficient of 53,3\%. This finding is consistent with previous research conducted by Jalilvand (2012) ${ }^{[15]}$ and Cynthiyadewi \& Jayammimi (2014) ${ }^{[16]}$. They say word of mouth is a communication that plays a large enough role in influencing and shaping consumer attitudes and intentions of these consumers. In addition, word of mouth can change the image that consumers form a company. With a strong and positive brand image, it will benefit a company. This will be the goods that will be the brand image of the company, then they will not be aware of the product or service to others.

Customer trust influences customer satisfaction according to Lin \& Wang (2005) $)^{[17]}$ and Li (2016) ${ }^{[18]}$. This influences with a path coefficient of $61,4 \%$. Trust plays an important role in encouraging customer satisfaction and buying interest. Currently, the community has believed in the services provided by GO-JEK, where the service is able to ease their activities. In addition, customers also have believed that the services provided are able to provide satisfaction to customers.

Customer trust ${ }^{[19]}$ and customer satisfaction ${ }^{[20]}$ also influence E-WOM. With each path coefficient of $29,6 \%$ and $33,5 \%$. Consumers who have confidence in a company and feel satisfied with the services or products offered will relatively talk positively about the company and its products. This is in line with descriptive analysis, which in the analysis states that respondents feel confident and satisfied with the GO-JEK application.

While for hypothesis testing of repurchase intention, EWOM has no effect on repurchase intention. However, brand image, customer trust, and customer satisfaction have an influence on repurchase intention. E-WOM doesn't have positive significant influences repurchase intention with a path coefficient of $13,3 \%$. This is because respondents are still reading bad comments about the company. However, it is not a barrier for customers to use the GO-JEK app. As long as GO-JEK is able to provide convenience to its users in 


\section{International Journal of Science and Research (IJSR) \\ ISSN (Online): 2319-7064}

Index Copernicus Value (2015): 78.96 | Impact Factor (2015): 6.391

using and finding the products or services they are looking for, customers will still come, so E-WOM does not significantly affect repurchase intention in PT. GO-JEK Indonesia.This finding doesn't consistent with previous research conducted by Jalilvand (2012) ${ }^{[15]}$.

According to Ebrahimi \& Tootoonkavan $(2014)^{[21]}$, brand image and customer satisfaction are influenced repurchase intention with each path coefficient of $22,7 \%$ and $31,6 \%$. Also, customer trust influences repurchase intention with a path coefficient of $23,6 \%$. This finding is consistent with previous research conducted by Lee et al $(2011)^{[22]}$, Fang et al $(2011)^{[23]}$, Mosavi \& Ghaedi $(2012)^{[24]}$, Aren et al $(2013)^{[25]}$, and then Amini \& Akbari (2014) ${ }^{[26]}$.

\section{Recommendation}

Based on the results of research conducted, it is known EWOM has no effect on the intention of buying back. This is because respondents feel they are still reading bad comments about GO-JEK. The bad comments happen because there are still customers who feel unbelieving and satisfied with the service they feel. It is appropriate with the results of data processing respondents' answers, where the greatest influence on customer confidence in customer satisfaction. The influence of these variables is $61.4 \%$. Thus, by increasing trust in customers, GO-JEK will be able to increase even greater customer satisfaction. In addition, by increasing customer satisfaction, it can also increase the intention to buy back. It is in accordance with the results of data processing of respondents' answers, where the greatest influence that encourages repurchase GO-JEK customer intention comes from customer satisfaction variable of $31.6 \%$.

One to improve customer satisfaction is by improving the service that will be provided to customers. By increasing customer satisfaction, GO-JEK will be able to increase even more repurchase interest. Suppose that when the user is having problems when using the application GO-JEK. Customer service should be able to solve the problems felt by the customer until the problem is over. Will, at this time the condition of the customer is still difficult to convey his complaints to the company so there are still customers who are less satisfied. In addition, there is a need for training for every GO-JEK driver. It turns out there are still customers who feel less satisfied with the services provided by the driver. As the driver brings his vehicle with 'inconsiderate', unfavorable vehicle condition, drivers stay on while driving (www.news.detik.com). Thus, there is a need for improved policies for customer service and drivers. Because both parties play a very important role, where they are full of direct customers.

\section{References}

[1] APJJI. (2014). Profil Pengguna Internet Indonesia 2014. [online]. Available

on http://www.slideshare.net/internetsehat/profilpengguna-internet-indonesia-2014-riset-oleh-apjii-danpuskakom-ui [Accessed: 28 Februari 2017].
[2] Widiartanto, Y. H. (2016). 2016, Pengguna Internet di Indonesia Capai $132 \quad$ Juta. [online].http://tekno.kompas.com/read/2016/10/24/1506 4727/2016.pengguna.internet.di.indonesia.capai.132.jut a. [21 Februari 2017]

[3] Kementrian Komunikasi dan Informatika. (2015). Buku Saku Hasil Survei Indikator TIK 2015 Rumah Tangga dan Individu. Jakarta: Badan Penelitian dan Pengembangan Sumber Daya Manusia.

[4] Waesche, N. (2015). Indonesia's Love Affair With Messaging - Top 15 Apps. [online]. Available on https://blog.gfk.com/2015/12/indonesias-love-affairwith-messaging-top-15-apps/. [Accessed: 21 Februari 2017]

[5] Benas, A. (2015). Ride Booking Trend in Jakarta Survey Report. [online]. Available on https://blog.jakpat.net/ride-booking-app-trend-injakarta-survey-report/. [Accessed: 22 Februari 2017].

[6] Gruen, T. W., Osmonbekov, T., and Czaplewski, A. J. (2006). eWOM: The Impact of Customer-to-Cistomer Online Know-How Exchange On Customer Value and Loyalty. Journal of Business Research, Vol. 59, pp. 449-456.

[7] Goyette, I., Bergeron, J., and Marticotte, F. (2010). eWOM Scale: Word-of-Mouth Measurement Scale for e-Services Context. Canadian Journal of Administrative Sciences, Vol. 27, pp. 5-23.

[8] Kotler, P., and Keller, K. L. (2013). Marketing Management. England: Pearson.

[9] Hawkins, D., dan Mothersbaugh, D. (2010). Consumer Behaviour. America, New York: McGraw-Hill.

[10] Mosavi, S. A., and Ghaedi, M. (2012). Role of Perceived Value in Explaining Trust and Repurchase Intention in E-Shopping. African Journal of Business Management, Vol. 6, pp. 4910-4920.

[11] Kotler, P., and Keller, K. L. (2016). Marketing Management $\left(15^{\text {th }}\right.$ Ed). England: Pearson.

[12] Zeithaml, V. A., et al. (2009). Service Marketing (5 ${ }^{\text {th }}$ Ed). New York: McGraw Hill.

[13] Kimppa, K., et al. (2014). ICT and Society: 11th IFIP TC 9 International Conference on Human Choice and Computers, HCC11 2014, Turku, Finland, July 30 . August 1, 2014. Heidelberg, New York, Dordrecht, London : Springer.

[14] Bohang, F. K. (2017). Go-Jek Klaim Kalahkan Grab dan Uber di Indonesia. [online]. Available on http://tekno.kompas.com/read/2017/06/13/18080087/go -jek.klaim.kalahkan.grab.dan.uber.di.indonesia. [Accessed: 16 Juni 2017].

[15] Jalilvand, M. R., and Samiei, N. (2012). The Effect of Electronic Word of Mouth on Brand Image and Purchase Intention: An Empirical Study in The Automobile Industry in Iran. Marketing Intelligence \& Planning, Vol. 30, pp. 460-476.

[16] Cynthiadewi, P. R., and Hatammimi, J. (2014). The Influence of Electronic Word of Mouth Toward Brand Image and Purchase Intention of $13^{\text {th }}$ Shoes. International Conference on Economics, Education and Humanities, 10-11 Desember, Bali, Indonesia.

[17] Lin, H. L., dan Wang, Y. S. (2005). An Examination of the Determinants of Customer Loyalty in Mobile 
Commerce Contexts. Information and Management, Vol. 43, pp. 271-282.

[18] Li, Y. (2016). Empirical Study of Influential Factors of Online Customers' Repurchase Intention. iBusiness, Vol. 8, pp. 48-60.

[19] Sallam, M. A. (2016). An Investigation of Corporate Image Effect on EWOM: Role of Customer Satisfaction and Trust. Journal of Business Administration, VO1. 7, pp. 27-35.

[20] Allahham, A., and Aljumaa, A. (2014). Analyzing Antecedents of Customer Satisfaction and its Impact on Word Of Mouth Communication in Life Insurance Services. International Journal of Management Sciences and Business Research, Vol. 3, pp. 29-35.

[21] Ebrahimi, M. R., and Tootoonkavan, S. (2014). Investigating the Effect of Perceived Quality, Perceived Value, Brand Image, Trust, Customer Satisfaction on Repurchase Intention and Recommendation to Other Case Study: LG Company. European Journal of Business and Management, Vol. 6, pp. 181-186.

[22] Lee, C. H., Eze, U. C., and Ndubisi, N. O. (2011). Analyzing Key Determinants of Online Repurchase Intention. Asia Pacific Journal of Marketing and Logistics, Vol. 23, pp. 200-221.

[23] Fang, Y. H., Chiu, C. M., and Wang, E. T. G. (2011). Understanding Customers' Satisfaction and Repurchase Intentions: An Integration of IS Success Model, Trust and Justice. Internet Research, Vol. 21, pp. 479-503.

[24] Mosavi, S. A., and Ghaedi, M. (2012). Role of Perceived Value in Explaining Trust and Repurchase Intention in E-Shopping. African Journal of Business Management, Vol. 6, pp. 4910-4920.

[25] Aren, S., Güzel, M., Kabadayi, E., and Alpkan, L. (2013). Factors Affecting Repurchase Intention to Shop at the Same Website. Procedia - Social and Behavioral Sciences, Vol. 36, pp. 537-544.

[26] Amini, M., and Akbari, H. (2014). Studying Effect of Site Quality on Online Repurchase Intention Through Satisfaction, Trust and Commitment of Customer. Indian Journal of Fundamental and Applied Life Sciences, Vol. 4, pp. 2839-2849.

\section{Author Profile}

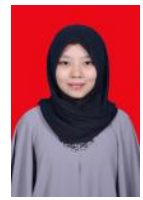

Ria Arumsari received the S.AB. degrees in Business Administration from Telkom University in 2015. 